\title{
A zenei fejlesztés lehetőségei diszlexiás tanulók esetében
}

\author{
Surján Noémi \\ Szegedi Tudományegyetem Neveléstudományi Doktori Iskola
}

\begin{abstract}
A tanulmány célja a zenei fejlesztések olvasási zavarra gyakorolt pozitív hatásának bemutatása az újabb hazai és nemzetközi kutatások tükrében. Ennek alapjául a zene és a nyelv közötti párhuzamok, illetve a zenetanulás széles transzferhatásai szolgálnak. A zenetanulás, a hangszeres játék ugyanis olyan mély neurológiai változásokat eredményez az agyban, amely egész életünkön át érezteti hatását. A szakirodalom alapján elmondható, hogy az olvasási zavar kezelését célzó zenei fejlesztésnek leginkább a ritmikai készség és a hangmagasság-észlelés fejlesztésére kell épülnie. A diszlexia megelőzésének és kezelésének új irányát jelentheti a hangszeren való tanulás, amely egy olyan komplex, magasabb kognitív folyamatokat igénylö tevékenység, ami a vizuális, auditív, szenzoriális és motoros készségek, képességek intenzív fejlődését eredményezi.
\end{abstract}

Kulcsszavak: diszlexia, zenei fejlesztés, ritmikai készség, hangmagasság-észlelés, hangszeres játék

\section{Bevezető}

A zenetanulás, a hangszeren való játék, mely komplexitásából fakadóan az észlelés és érzékelés széles skáláját fedi le és magasabb rendủ kognitív folyamatokat igényel, olyan átfogó neurológiai változásokat eredményez az agyban, mely egész életünk alatt érezteti hatását (Weiss, Gavin és Bidelman, 2015). A zenészek és nem-zenészek közti összehasonlító vizsgálatok különböző agyi strukturális változásokra is rámutatnak. Kiemelik a zenészek szürkeállományának a hallásfeldolgozáshoz és a motorikus funkciókhoz kapcsolódó területeinek gazdagabb huzalozását (Gaser és Schlaug, 2003; Musacchia, Strait és Kraus, 2008), a két agyfélteke közötti kapcsolat jobb kiépültségét, és többek között az anyanyelv és az idegen nyelv észlelésének, feldolgozásának javulását (Musacchia és mtsai, 2008; Weiss és mtsai, 2015). A zenetanulás, multiszenzoriális jellegéből fakadóan és az agyi plaszticitásra gyakorolt pozitív hatása révén, alkalmas lehet a tanulási képességek fejlesztésére. Több, a zenei fejlesztésre épülö kísérlet számolt be pozitív irányú fejlődésröl az egyes iskolai képességek és az azokkal összefüggést mutató részképességek, illetve a figyelem, a megoldási stratégiák (Kokas, 1972), a végrehajtó funkciók (Tierney és Kraus, 2013), a kreativitás (Barkóczi és Pléh, 1978) és a mozgáskoordináció (Gaser és Schlaug, 2003; Musacchia és mtsai, 2008) területén. A zenetanulás transzferhatásaira építve így a tanulási nehézséggel, zavarral küzdők fejlesztése is új lendületet kaphat. Jelen tanulmány a zenei fejlesztések olvasásra gyakorolt hatásainak újabb eredményeit hivatott összegezni, melyek gyakorlatban is megvalósuló alkalmazása hatékony módját jelentheti a diszlexia megelőzésének, kezelésének.

\section{A zene és a nyelv kapcsolata}

Az emberiség legjellegzetesebb tulajdonsága a gondolkodás és az a másodlagos jelzörendszer, a beszéd és a nyelv, mely mindezt közvetíti, kiszolgálja. Az olyan nagy gondolkodók, mint Rousseau és Darwin, a nyelvet a zenével párhuzamba állítva, kö- 
zös tőről eredeztették azokat, amely nézetnek azóta is számtalan követője van. Bernstein (1979) közös strukturális és funkcionális vonásokat állított fel a zene és a nyelv között Chomsky nyelvészeti fejtegetéseiből kiindulva: a fonémákat a zenei hangokkal, a szavakat a zenei motívumokkal, a mondatokat a zenei mondattal párhuzamba állítva. Mindkét hierarchikus rendszer alapeleme tehát maga a hang, mely bár önmagában jelentéssel nem rendelkezik, magasabb strukturális egységekbe rendeződve azonban telítődhet azzal.

A beszéd és a zenei tartalom, így a hang, ugyanazon akusztikai tulajdonságok mentén szerveződnek, melyek a hangmagasság, az időtartam, az intenzitás és a hangszín (Besson, Chobert és Marie, 2011). Ezen tulajdonságjegyek variálása kommunikációs funkcióval rendelkezik mind a zene, mind pedig a beszéd területén. Közös vonásaik, tartalomközvetítő szerepük az agyi feldolgozás hasonlóságának lehetőségét is magában hordozza. Mindkettő előállítása ugyanis a hang különböző tulajdonságainak kontrollálásának képességén alapul és eredményez változást a hang alapvető struktúrájában (Zatorre és Baum, 2012). Agyi képalkotó eljárásokkal vizsgálva a zenei és a nyelvi struktúra feldolgozási folyamatait, hasonló bilaterális agyi területek aktivizálódását figyelték meg az alsó homloktekervény, illetve a Broca-terület és annak szimmetrikus megfelelője esetében (Tillmann, 2012). További kölcsönhatásokat jegyeztek fel a hangmagasság-észlelés fejlettségének a nyelvi hangmagasság-információk dekódolására kifejtett pozitív hatásáról, melynek alapját a szubkortikális és kortikális struktúrák közötti interakció képezi (Wong, Skoe, Russo, Dees és Kraus, 2007). Mindezekböl kiindulva a zene és a nyelv feldolgozási folyamatainak közös idegi alapját feltételezik, amely hídként szolgálhat a zenei képességek és a fonetikai, illetve prozódiai képességek között (Patel és Iversen, 2007). E kapcsolat pontos feltérképezése jelenleg is tart, ám már az eddigi eredmények is a beszéd és a zene kapcsolatát hangsúlyozzák.

A zenei és beszédhang hasonló kognitív feldolgozása és idegi alapja a hangmagasság leképezésében egyedi utakat is mutat az eltérő információjellegből fakadóan. Zatorre és Baum (2012) két külön mechanizmust feltételeznek emögött: egyet, amely a hang kontúrjára fókuszál és valószínűleg kapcsolatot teremt a különböző agyi területek között, és egy másikat, amit zenespecifikusnak vélnek, és vélhetően a hang pontos kódolását, előállítását végzi. Az agyi feldolgozást vizsgálva a bal hallókérgi területek az időbeli tényezők kapcsán magasabb fokon reagálnak, ami a hangzók megkülönböztetésében játszik szerepet, míg a megfelelő jobb oldali területek jobb spektrális érzékenysége a hangmagasság-észlelésnél (Zatorre, Belin és Penhune, 2002), illetöleg az olyan extra nyelvezeti funkciók esetében releváns, mint az érzelmek, a szándék és a személy azonosítása (Kraus és Chandrasekaran, 2010). A zenészek hangkontúr-észlelését vizsgálva Weiss és mtsai (2015) már kis eltérés észlelése esetén is jobb eredményeket kaptak, mint nem-zenészeknél, ami a beszéd hangsúlyozásának, hanglejtésének felismerésében jelent előnyt.

A zene és a beszéd észlelésének kulcsfontosságú részét képezi a hangok, hangzók megkülönböztetésének képessége, ami a szavak fő vázát alkotó mássalhangzók esetében 160 milliszekundumnál rövidebb idő alatt kell, hogy végbemenjen, míg a zenei dallamot alkotó hangok esetében hosszabb időtartam áll a rendelkezésünkre (Zatorre és mtsai, 2002). Ezt a megkülönböztetést segíti az az időbeli skála, amely mind a zene, mind a beszéd kapcsán megjelenik, struktúrába rendezve a hangokat. A zenében mindez kiegészül még a tonalitás és az összhangzattani funkciók, a zenei szerkezet értelmezésével, melynek még legkisebb, hangokból felépülő egysége, a motívum is állandó feszítés-oldás érzetét hordozza. A beszédben jelentkező hasonló 
ritmust a különböző típusú prozódiai feszültségek (pl. lexikai, hangi és empátiai feszültség), a beszéd, a nyelv dallamossága, hangsúlyozásbeli sajátosságai hordozzák. A metrikai ritmus így a zenében és a beszédben valószínüleg közös agyi temporális feldolgozási területeket érint (Cason, Astésano és Schön, 2015).

További kapcsolódási pontként jelenik meg mindezek mellett, hogy a zene és a hangszeren való játék olyan magasabb szintű kognitív elvárásokat igényel az egyéntől, ami mélyreható neurológiai változásokat eredményez az agyi folyamatokban (Weiss és mtsai, 2015), a hangszeres játék állandó monitorozása pedig a multimodális észlelést és a motoros információk folyamatos ellenőrzését, visszajelzését követeli meg (Gaser és Schlaug, 2003). Ezen feldolgozási folyamatok között helyet kap többek között a szekvencialitás, a figyelem, a memória és a tanulás, melyek más képességterületeken is megjelennek, és így a zenei fejlesztés pozitív hatással lehet rájuk (Francois, Chobert, Besson és Schön, 2012). Ezt a kapcsolatot támasztja alá az is, hogy a nyelvi feldolgozás során megjelenő deficitek a zenei feldolgozás során is jelentkeznek (Giacobbe, 1972). A zene és a beszéd közös feldolgozási folyamataiból kiindulva több kutató is elkötelezte magát amellett, hogy a zenei fejlesztés pozitívan befolyásolhatja a különböző nyelvi képességeket, és hatékony rehabilitációs módja lehet a különböző motoros és kognitív nehézségeknek, zavaroknak (Flaugnacco, Lopez, Terribili, Zoia, Buda, Tilli, Monasta, Montico, Sila, Ronfani és Schön, 2014).

\section{A diszlexia, az olvasást érintő tanulási zavar}

A diszlexia kifejezés az olvasás gyengeségére utal, melyet a különböző tudományterületek eltérő tényezőket kiemelve írnak le. Orvosi szemszögből a diszlexia a központi idegrendszer elváltozása miatt alakul ki, a pszichológiai megközelítés alapján részképességzavar következménye, pedagógiailag pedig az iskolai teljesítmény és az intellektuális képességek közötti jelentős eltérésként írják le (Gyarmathy, 2007). A diszlexia az olvasástanulás nehézségében megtestesülő zavar, melynek fő típusait a DSM-V (American Psychology Association, 2013) a megjelenő problémakörök szerint a következő nehézségek mentén csoportosítja: az olvasás pontossága, az olvasás sebessége és folyékonysága, valamint az olvasott szöveg megértése. Hazánkban ez az általános iskolás populáció mintegy 15\%-át érintő probléma (Gyarmathy, 2013), melyböl súlyos zavarokkal 3-8\%-uk küzdhet (Dékány és Mohari, 2012).

Az olvasást érintő részleges teljesítményzavar mögött meghúzódó fő ok az agy egy részének késedelmes érése, illetve annak enharmonikus működése (Csépe, 2006; Gyarmathy, 2013). Mindez visszavezethető az öröklődésre, lateralitásbeli problémára, észlelési nehézségekre, sajátos emlékezetzavarra vagy valamilyen anatómiai károsodásra (Lohmann, 2000). Diszlexiások agyi folyamatait vizsgálva egy agyi területnek, a temporális lebeny bal felső tekervényének alacsony aktivációs szintje általános jellemvonásnak tünik a kutatások tükrében. Ez a terület vesz részt a graféma-fonéma átalakításban, amelynek olvasás közbeni alulmüködését a gyerekek az agy frontális területének megnövekvő aktivációjával igyekeznek kompenzálni (OECD, 2009). Mindemellett alapvető deficitek figyelhetőek meg az időzítési képességekben, melyek a diszlexia esetében jelen lévő fonológiai gyengeség, hallási és vizuális észlelési nehézségek, a gyors megnevezés nehézsége és a nagy és finommotoros mozgás kivitelezésének közös alapját képezhetik (Overy, 2003).

A diszlexia esetében jelen lévő neurológiai deficitek érinthetik a testséma kialakulását, az egyensúlyrendszert, a téri-orientációs képességeket, szenzo-motoros integrációt, illetve okozhatnak még szeriális gyengeséget, szövegértési nehézségeket. 
Az olvasási nehézség mellé így gyakran más problémák is társulnak. Felléphet valamilyen írási nehézség, de megjelenhet hiperaktív viselkedés, szorongás, figyelemzavar és magatartászavar is.

A diszlexiások gondolkodása, információfeldolgozása eltér az átlagtól, és erősen a jobb agyféltekei funkciókra épít (Gyarmathy, 2007), melynek okán a bal agyféltekei gondolkodást preferáló iskolai oktatásban sokszor nehézségekkel küzdenek. Mindezt a kultúránkban és életmódunkban bekövetkező változások is felerősítik, melyek a gyermekek fejlődését a megszokottól eltérően alakítják. Fejlődésükből olyan fontos tapasztalati élmények esnek ki, mint a hagyományos játékok. Emellett a családi időtöltések átalakulása, hiánya is számtalan zavart okozhat a gyermekek fejlödésében (Gyarmathy, 2013). Mindezzel az iskola jelenleg még nem tudja felvenni a lépést, lineáris felépítést követő szisztematikus tudásátadása digitális társadalmunk gyerekei számára sokszor az unalom, illetve a kudarcok színhelyévé teszi az iskolát. Ezt támasztja alá Józsa, Wang, Barrett és Morgan (2014) vizsgálata is, melyben az elsajátítási motiváció iskolai évek alatt bekövetkező jelentős csökkenéséről számolnak be nemcsak hazánkban, hanem más országokban is. Mindemellett az iskolában eltöltött évek számának növekedésével párhuzamosan a tanulási motiváció folyamatos csökkenése is megfigyelhető, mely a 10 és 14 év közötti korosztály tekintetében $61 \%$-os arányt képvisel (Józsa és Morgan, 2014).

A modern társadalmunk fontos elvárásaként megjelenő funkcionális írni-olvasni tudás elsajátítása így az iskolarendszer keretein belül nehézségekbe ütközik, amely alapvetően a szimbólumok ismeretén túl azok kreatív, alkotó alkalmazásával a tudás gyarapítását szolgálná. A tanulási nehézséggel, zavarral küzdő tanulók számának az oktatási statisztikák által kimutatott folyamatos növekedésében az iskolai oktatás rugalmatlansága, a társadalmi folyamatokra való lassú reagálás és a nem megfelelöen megválasztott oktatási stratégiák, módszerek alkalmazása is szerepet játszhatott. Emellett a téves diagnosztika lehetőségét hordozza még magában az óvodai évek alatt lezajló intenzív fejlődés megkésettsége, mely az iskolába kerülve jelentősen megnehezítheti ezen gyermekek számára az elemi készségek elsajátítását, és a tanulási zavarhoz hasonló problémákat okozhat (Józsa, 2016).

A megelőzés és a kezelés egy komplex, több éven át tartó folyamatba kell, hogy rendeződjön, és súlyos diszlexia esetén akár mint életviteli sajátosság is megjelenhet. Az olvasási zavar problémakörét a korai gyanú stádiumában, lehetőség szerint már az óvodai évektől kezdve ajánlott célzottan kezelni. Ennek a szenzomotórium rendszere (1. táblázat) adhat keretet, amelynek három fő területét az életkor előrehaladtával, a szenzitív időszakoknak megfelelően, folyamatosan kell bevinni a megelőzésbe (Gyarmathy, 2015).

\begin{tabular}{|c|c|c|c|}
\hline \multirow{7}{*}{ 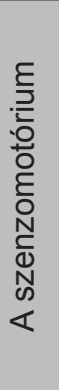 } & Mozgás & $\begin{array}{c}\text { Térorientáció } \\
\text { Egyensúly } \\
\text { Testséma }\end{array}$ & kiscsoport \\
\hline & \multirow{3}{*}{ Észlelés } & Látás & \multirow{3}{*}{ középső csoport } \\
\hline & & Hallás & \\
\hline & & Tapintás & \\
\hline & \multirow{3}{*}{ Szekvencialitás } & Téri & \multirow{3}{*}{ nagycsoport } \\
\hline & & Idői & \\
\hline & & Nyelvi & \\
\hline
\end{tabular}

1. táblázat: A szenzomotórium (Gyarmathy, 2015 előadása alapján) 
Az iskolai évek alatt ezen területek más-más szemszögből, de folyamatosan fejlődnek, melynek egy speciális módjaként maga a zenetanulás is megjelenhet. A zenei képességek szempontjából ugyanis a szenzitív periódus nem pusztán az óvodás kort, hanem az iskolai éveket is érinti, hároméves kortól egészen kilenc éves korig tart (Janurik és Józsa, 2016c). A zenetanulás, a hangszeres játék multimodális és multiszenzoriális megközelítést biztosít, amely a minél hatékonyabb előrehaladás, fejlesztés biztosítékaként szolgál a diszlexia esetében.

\section{A zenei képességek rendszerezése}

A zenei képességek rendszerét illetően többféle modell is született, melyek elveikben megegyeznek, és az eredményes zenei tevékenységhez több képesség egyidejü meglétét elengedhetetlen feltételnek tekintik (Erős, 1993; Janurik, 2008). Ezen képességek fejlődését az egyén környezete, adottságai és az oktatás is befolyásolja (Janurik és Józsa, 2016c). Alapját minden egyes esetben a zenei észlelés képezi (Janurik és Józsa, 2013), amely különböző kognitív feldolgozási folyamatok segítségével a zene értelmezését teszi lehetővé.

A zenei képességek feltárásának kutatása a huszadik század elején indult meg a muzikalitás jelenségének tanulmányozása kapcsán. Az egyik első rendszerezés Seashore (1919) nevéhez köthető, akinek zenei képességrendszere az egyik legátfogóbb elképzelés. Huszonöt zenei képességet oszt fel öt fö csoportba, melyeket a következőképpen (2. táblázat) szemléltethetünk:

\begin{tabular}{|c|c|c|}
\hline \multicolumn{2}{|c|}{ Föbb csoportok } & Zenei képességek \\
\hline \multirow{2}{*}{$\begin{array}{l}\text { I. Zenei érzékelés és } \\
\text { érzékenység }\end{array}$} & $\begin{array}{l}\text { az érzékelés } \\
\text { egyszerü } \\
\text { formái }\end{array}$ & $\begin{array}{l}\text { 1. a hangmagasságérzék } \\
\text { 2. a hangerősségérzék } \\
\text { 3. időérzék } \\
\text { 4. a hangkiterjedés iránti érzék (extensity) }\end{array}$ \\
\hline & $\begin{array}{l}\text { az érzékelés } \\
\text { bonyolult formái }\end{array}$ & $\begin{array}{ll}\text { 5. } & \text { ritmusérzék } \\
\text { 6. } & \text { hangszínérzék } \\
\text { 7. } & \text { konszonancia iránti érzék } \\
\text { 8. } & \text { a hang testessége iránti érzék (volumen) }\end{array}$ \\
\hline \multicolumn{2}{|c|}{ II. Zenei tevékenység } & $\begin{array}{l}\text { 9. a magasság ellenőrzése } \\
\text { 10. a hangerősség ellenőrzése } \\
\text { 11. idő ellenőrzése } \\
\text { 12. ritmus ellenőrzése } \\
\text { 13. hangszín ellenőrzése } \\
\text { 14. a hang testességének ellenőrzése }\end{array}$ \\
\hline \multicolumn{2}{|c|}{$\begin{array}{l}\text { III. Zenei emlékezet } \\
\text { és zenei képzelőerő }\end{array}$} & $\begin{array}{l}\text { 15. hallási képzetek } \\
\text { 16. mozgásképzetek } \\
\text { 17. alkotóképzetek } \\
\text { 18. az emlékezés mértéke } \\
\text { 19. a tanulásra való képesség } \\
\end{array}$ \\
\hline \multicolumn{2}{|c|}{ IV. Zenei értelem } & $\begin{array}{l}\text { 20. szabad zenei képzettársítások } \\
\text { 21. a zenei reflexiós képesség } \\
\text { 22. általános értelmi adottság }\end{array}$ \\
\hline \multicolumn{2}{|c|}{ V. Zenei érzelem } & $\begin{array}{l}\text { 23. zenei ízlés } \\
\text { 24. érzelmi reagálás a zenére } \\
\text { 25. önmagunk emocionális kifejezése a zenében }\end{array}$ \\
\hline
\end{tabular}

2. táblázat: Seashore zenei képességmodellje 
Az egyes személyek zenei tehetségét minden egyes - fent említett - tényező befolyásolja (Gombás és Stachó, 2006), és elképzelésének összetettségét jól mutatja, hogy a modell zenén kívüli tényezőket is tartalmaz, melyek a 3., 4. és 5. csoportban kaptak helyet. Tyeplov (1960) kiemeli, hogy az első három szenzorikus képesség - a hangmagasságérzék, a hangerősségérzék és az időérzék - alapvető jelentőségű, és bár egymástól függetlenek, a többi képességet befolyásolják.

Moles 1966-ban a hang általános tulajdonságaként szintén az időtartamot, a magasságot és az erősséget emelte ki, és ezek alapján öt dimenziót hozott létre: ritmus, dinamika, melódia, hangszín, harmónia (Tyeplov, 1960). Gordon (1989, idézi Gombás és Stachó, 2006) emellett kihangsúlyozza a zenén kívüli tényezők fontosságát is a zenei képesség formálásában, és új fogalmat hoz létre, az audiációt (audiation). Ezt, a hallásból eredeztethető képességet a nyelvvel állítja párhuzamba (Turmezeyné, Máth és Balogh, 2005), és olyan feldolgozási folyamatként jelöli meg, mely a zene értelmezésében tölt be fontos szerepet, és amelynek fejlettségével az egyén zenei képessége hatékonyan meghatározható (Gombás és Stachó, 2006).

Az Erős (1993) által felállított képességmodellben a zene és a kommunikáció párhuzama tovább fokozódik, a zenei alapképességet a zenei dimenziók rendszeréből és a zenei kommunikáció síkjaiból építi fel. A Moles által megalkotott, a zenei hangot jellemző dimenziók mellett a zenei kommunikáció funkcióiként a zenei hallást, zenei közlést, zenei olvasást és zenei írást különbözteti meg (Erős, 1993). Ezt az összetett rendszert a következőképpen ábrázolhatjuk (3. táblázat):

\begin{tabular}{|c|c|c|c|c|}
\hline \multirow{2}{*}{$\begin{array}{c}\text { Zenei } \\
\text { tartalmak }\end{array}$} & Hallás & Közlés & Olvasás & Írás \\
\cline { 2 - 5 } & Dallamhallás & Dallamközlés & Dallamolvasás & Dallamírás \\
\hline Melódia & Harmóniahallás & Hangzatközlés & Hangzatolvasás & Hangzatírás \\
\hline Harmónia & Ritmushallás & Ritmusközlés & Ritmusolvasás & Ritmusírás \\
\hline Ritmus & Hangszínhallás & - & - & - \\
\hline Hangszín & Dinamikahallás & - & - & - \\
\hline Dinamika & - & & - & - \\
\hline
\end{tabular}

3. táblázat: A zenei alapképességek kétdimenziós modellje (Erős, 1993)

A hallási dimenzió az egész zenei észleléssel kapcsolatban áll, állandó visszacsatoló funkciójával központi szerepet tölt be a zenei folyamatok értelmezésében és a megfelelő interpretáció megvalósításában. Ez képezi mindenféle zenei tevékenység alapját, és ezért a hallási feldolgozó készségek fejlesztése a zenei fejlesztések kapcsán is döntő szerepet játszik.

Továbbá, ahogy a zenei hallás és zenei közlés is megfeleltethető a kommunikációs modell adó-vevő relációjának, úgy a zenei írás és olvasás is összefüggésbe hozható a nyelvi szövegek írásával, olvasásával. A két tevékenység - írás és olvasás - mindkét esetben ellentétes funkciót tölt be: a nyelv függvényében a graféma-fonéma kapcsolat oda-vissza alakításáról, a zene kapcsán pedig olvasáskor a leírt jelek hangzássá változtatása és íráskor a hallott hangzás jelekként való lejegyzése történik. Az itt vázolt párhuzam még tovább fokozható, hiszen ahogy a zenei produkció és lejegyzés is megkövetel egyfajta belső hallást, előzetes reprezentációt, úgy ehhez hasonlóan a nyelvi készségek terén egyfajta belső beszéd meglétét is alátámasztják a kutatások (Marton-Dévényi, 2001). A két terület szoros összekapcsolódását a különböző zenei transzferhatások vizsgálata során is bebizonyították. 


\section{A zenei transzferhatások vizsgálata}

A zene transzferhatásainak, vagyis a már megszerzett tudás más szituációkban való hatékony alkalmazhatóságának vizsgálata hazánkban Kokas Klára (1972) kutatásaival vette kezdetét. A kodályi elveknek és a mindennapos énekoktatásnak távoli transzferét igazolta a helyesírás, a matematika területén, illetve a figyelem fenntartása és a hatékonyabb megoldási stratégiák használata terén a zeneoktatásban nem részesülő kontrollcsoporthoz képest.

További kutatások kiemelték a zenetanulás pozitív hatását a kreativitásra, a szociális háttér-kompenzációra vonatkozóan (Barkóczi és Pléh, 1978), míg Zsolnai és Józsa $(2002,2003)$ zeneterápiás módszereket használva a szociális készségek fejlődésében tapasztaltak kisiskolások körében jelentős eredményeket. Az intelligencia és a zenetanulás pozitív korrelációját Schellenberg (2004) támasztotta alá, az iskolai tantárgyak kapcsán pedig a végrehajtó funkciók (Tierney és Kraus, 2013) és a geometriai reprezentáció (Gazzaniga, 2008), illetve a problémamegoldó-gondolkodás (Gombás és Stachó, 2006) mutatott összefüggést.

Babo (idézi Janurik, 2008) a jobb tantárgyi teljesítmény mellett leginkább az olvasás és a nyelvi készségek fejlődésében tudott a többi tantárgyhoz képest nagymértékü fejlődést kimutatni a zenét tanulók között. A zenei fejlesztés olvasásra gyakorolt pozitív hatását többen is alátámasztották (Kraus, Slater, Thompson, Hornickel, Strait, Nicol és White-Schwoch, 2014; Levitin, 2006; Moreno, Marquez, Santos, Castro és Besson, 2009; Tiernay és Kraus, 2013; Thomson és Goswami, 2008), Moreno (idézi Janurik, 2008) pedig kimutatta, hogy ez mind a ritmus-, mind pedig a melódia-, a harmónia- és a hangszínészlelés fejlesztése esetében érvényesül. További, specifikusabb összefüggéseket vizsgálva a zenei képzés pozitív hatása tapasztalható a fonológiai tudatosság (Flaugnacco és mtsai, 2014; Huss, Verney, Fosker, Mead és Goswami, 2011; Overy, 2003) és a beszédfeldolgozás (Bishop-Liebler, Welch, Huss, Thomson és Goswami, 2014; Cason, Astésano és Schön, 2015; Wong és mtsai, 2007) esetében, melynek alapját a zene és a nyelv közötti párhuzamok képezik.

Az utóbbi években a zenei fejlesztés hatásait vizsgáló kutatások száma igencsak megnövekedett, és előtérbe került a tanulási zavarral küzdők, illetve tanulási akadályozottsággal rendelkezők körében történő alkalmazása. Ennek alapját a zenetanulás széles transzferhatásai képezik, melyek az egyes zenei készségek, kiemelten a ritmikai készség és a hangmagasság-észlelés, fejlesztése révén többek között az agyi folyamatokra, az idői érzékelésre, a figyelem fenntartására is jótékonyan hatnak. Kijelenthető, hogy ezen hatások pozitívan befolyásolják a különböző tanulási készségeket, képességeket, ám a pontosan mi és miért, milyen mértékben kérdésekre eltérő válaszok születnek. Ennek hátterében a zenei hallás feldolgozási folyamatainak magyarázatául szolgáló különböző elméletek, valamint a tanulási problémák nem egységes fogalomrendszere állhat, illetőleg az a kezdetinek mondható jelenlegi fázis, melyben rövid távú, direkt fejlesztési programok megvalósulása történik a tanulók további követése nélkül.

\section{A zenei fejlesztések perspektívái}

A zene elsődleges befogadása alapvetően hallás útján történő feldolgozással történik. Ez képezi mindenféle zenei tevékenység alapját, és ezért a zenei fejlesztések kapcsán is döntő szerepet játszik a hallási feldolgozó készségek fejlesztése. A következőkben a hangszeres játék, a hangmagasság-észlelés és a ritmus transzferhatásairól kialakult 
újabb eredményeket ismertetem. Ezek a diszlexiával küzdő tanulók fejlesztése kapcsán fontos szerepet tölthetnek be, mivel különböző, minőségi neurális változásokat eredményeznek az agyi folyamatokban (Peretz és Zatorre, 2005), és a zenélés által lehetőséget biztosítanak a diszlexiásokra jellemző jobb agyféltekéhez kötődő kreativitás kibontakoztatására, és ezáltal a sikerélmény átélésére.

\section{Hangszeres játék}

A zenélésről általánosan elmondható, hogy olyan élvezetes tevékenység, mely ugyanakkor magas kognitív követelményeket támaszt a játékos felé. A zenész feladata lényegében a zenei darab struktúrájának és érzelmi tartalmának átadása a hallgatóság számára, amelynek megvalósulását a finoman koordinált motorikus mozgások teszik lehetővé. Ez egy tipikusan olyan feladat, amely a szenzoriális és motoros készségek, képességek összehangolását igényli, mely által az agyféltekék közötti összeköttetés megerősíthető. Ez, az általánosan jobb agyféltekés gondolkodással rendelkező diszlexiások esetében különösen hasznos, hiszen az új kapcsolódási pontok kiépülése segíti az információk szabadabb áramlását, az eltérő feldolgozási módok lehetőségének megteremtését.

Zenészek és nem-zenészek agyi képalkotó eljárásokkal történő összehasonlító vizsgálatai jelentős eltérésekről számolnak be, melyek érintik a szürkeállomány auditív, motoros és vizuális feldolgozással kapcsolatos régióit (Gaser és Schlaug, 2003; Musacchia és mtsai, 2008; Zatorre, 2013). Az agy mozgással foglalkozó területeit vizsgálva mind strukturálisan (Gaser és Schlaug, 2003), mind funkcionálisan (Krings és mtsai, 2000) fejlődést tapasztalhatunk a zenélési tapasztalatok növekedésével. Ezen területek fejlesztésének jelentősége a diszlexiások esetében azért válik kiemelten fontossá, mert a mozgásirányítás mellett a tervezésben, az előkészítésben és a végrehajtásban is funkcióval rendelkeznek (Gaser és Schlaug, 2003). A hangszeres játék során fejlődő motoros képességek egyben olyan fontos szomatoszenzoriális területek aktiválását is igénylik, mint a tapintás, a lábak és a karok használata, mely fúvós hangszerek esetében tovább bővül az arc izmainak, az ajkaknak és a nyelvnek a használatával. Jelen esetben tehát egy összetett, többféle mozgási mintázatot irányító cselekvésröl beszélhetünk, amelynek türelmes fejlesztése segítségünkre lehet a finommozgások koordinálásának és a lateralitásbeli problémák által okozott nehézségek orvoslásában.

A hallás az elsődleges kontrollt képviseli a hangszeres játék során, és így az auditív feldolgozási képességek fejlődésével jár. Zenészek esetében a nyelvi észlelés mind az anyanyelvre, mind az idegen nyelvre vonatkozóan fejlettebb, mint nem-zenészeknél (Musacchia és mtsai, 2008). A zenészek a különböző vizsgálatok tükrében a hangmagasság kontúrjainak észlelésében jobban teljesítenek, mint a zenei képzettséggel nem rendelkezők, ami a beszélő szándékának megfelelő hangsúlyozásban tölt be fontos szerepet (Kraus és Chandrasekaran, 2010; Moreno és mtsai, 2009). Emellett azok a gyermekek, akik zenei fejlesztésben vesznek részt, erősebb neurális reakciókat mutatnak az anyanyelvi hangmagasság-infomációk észlelésében, jobb a verbális memóriájuk, szókincsük és olvasási teljesítményük is magasabb (Moreno és mtsai, 2009). A zenei fejlesztés tehát olyan általános hallásfeldolgozási területeket érint, melyeknek szerepe lehet a beszéd észlelésének javulásában (Francois és mtsai, 2012; Kraus és Chandrasekaran, 2010; Tallal és Gaab, 2006).

Hangszeres játék esetén a vizuális feldolgozás a kottaolvasás kapcsán jelentkezik. Ennek a szimbólumrendszernek az értelmezése kezdetben bonyolult feladatot jelent, hiszen többféle információtípus egyidejü értelmezését kívánja meg. Az olyan mögöttes 
tartalmak, melyeket az előadói utasítások és a formatani szerkezet képvisel, a darab és az érzelmek értelmezésében játszanak szerepet. Interpretálásuk magasabb hangszerkezelési és kognitív ismereteket igényel, elsajátításuk és fejlődésük pedig apránként történik a hangszeres tanulmányok előrehaladásával párhuzamosan. A hangmagasság és a ritmus viszont a kotta legalapvetőbb információi, melyeknek lejegyzési módjai az ókortól folyamatosan fejlődtek egészen a napjainkban használt rendszerig. E kettő, olvasását tekintve, eltérő feldolgozást igényel, hiszen a hangmagasság a térbeli elhelyezkedés, a ritmus pedig különböző egyezményes jelek kódolását kívánja meg. A továbbiakban ezen zenei tulajdonságokat és fejlesztő hatásukat ismertetem.

\section{Hangmagasság-észlelés}

A hangmagasság értelmezése a zenei struktúra feldolgozásának fontos elemét képezi, és kiemelt szerepet kap a különböző nyelvi információk kódolása során. A nyelvben a hangmagasság elsődleges megjelenési formáját a prozódia, a hangsúlyozás jelenti, mely egyes nyelvek esetében a lexikai jelentések elkülönítésében is szerepet kap. A kommunikációban emellett a hangmagasság a különböző érzelmi állapotok közvetítését látja el, mely a beszéd kódolása során fontos jelentőséggel bír.

Wong és mtsai (2007) kimutatták, hogy a hosszú távú zenei képzésnek pozitív hatása van a nyelvvel összefüggő hangmagasság-információk dekódolására az agytörzsben. Musacchia és mtsai (2008) emellett kiemelik, hogy zenészeknél a hangmagasság periodicitásának szilárdabb reprezentációi, és az észlelt hangok gyorsabb feldolgozása figyelhető meg, amikor a hangot hallják, vagy hallgatják és nézik a beszélőt.

Alapvetően az eddig a témában lezajlott vizsgálatok kiemelik, hogy a hangmagasság-megkülönböztetés fejlődésének előremozdító hatása van az olvasási zavarral, nehézséggel küzdők körében, azonban viszonylag egyhangú egyetértés mutatkozik azt illetően, hogy a ritmikai fejlesztés szignifikánsabb változásokat eredményez teljesítményükben.

\section{Ritmikai készségek}

A ritmika az emberi élet és az emberi szervezet alapvető szervező ereje, melynek egyfajta megjelenését képezi a zene. A zenei hangok struktúrába rendeződését eredményezi, mely dallamok és zenei formák feldolgozását teszi számunkra lehetővé, így segítve a zene mint jelentéssel bíró hangstruktúra értelmezését.

A zenei ritmikának alapvetően két fő rendezőelvét különböztethetjük meg: a lüktetést, mely az ütem súlyos-súlytalan ütéseinek relációin alapul, és magát a ritmust, mely a hangok egymáshoz való időbeli viszonyulását határozza meg. Bár e kettő szoros kapcsolatban áll, zenei feldolgozásuk során az agyi féltekék szerepe mégis eltérő. Ibbotson és Morton (1981) kiemelik a jobb félteke metrumtartásban, és a bal félteke ritmikai csoportosításban betöltött nagyobb szerepét. A beszéd során alkalmazott hangsúlyos hangzók és a zenében jelenlévő hangsúlyos ütések között felállítható párhuzam az időbeli elhelyezkedés révén lehetővé teszi a beszéd feldolgozásának könnyebb érthetőségét (Gordon, Magne és Large, 2011). Ezen feltételezésekböl kiindulva, több kutató is bebizonyította a zenei ritmika beszédfeldolgozásra, azon belül pedig a fonológiai tudatosságra gyakorolt pozitív transzferhatását (Cason és mtsai, 2015; Huss és mtsai, 2011).

A zenei hang értelmezési alapját a zenei folyamatban betöltött szerepe jelenti, melyet a dallami és harmóniai viszonyrendszer függvényében maga a hangmagasság és a ritmika képvisel. Ez párhuzamba állítható a nyelv prozódiai struktúrájával, ame- 
lyet Port (2003) fonológiai nyelvtanként definiál. Az eddig lezajlott, a zene és beszéd közti ritmikai megfeleléseket tanulmányozó vizsgálatok rámutatottak arra, hogy fejlödési diszlexia esetében ritmikai és metrikai feldolgozási nehézségek is megjelennek (Flaugnacco és mtsai, 2014; Huss és mtsai, 2011).

Egy ritmikai fejlesztés tehát pozitívan hathat a hallási képességek fejlődése által a beszéd ritmikájára való érzékenységre, hiszen a zenei hangok és fonémák elkülönítésében a gyors időbeli feldolgozásnak és az apró ritmikai eltérések észlelésének kiemelt szerepe van (Overy, 2003). E kapcsolat fontosságát hangsúlyozzák BishopLiebler és mtsai (2014) is, akik kiemelik ezen fejlesztés szenzitív időszakaként a gyermekkort. A zenei fejlesztés erejét az audio-motoros területek együttes ingerlése képezi, mely a metrikai eltérésekre való érzékenység mellett (Gaiser, Sandmann, Jancke és Meyer, 2010; Vuust és mtsai, 2005) a ritmuspercepcióra is erős hatást gyakorol (Philips-Silver és Trainor, 2005; Su és Pöppel, 2012). A zenei fejlesztés szignifikáns pozitív hatását emeli ki mindezek mellett Overy (2003) a ritmusreprodukció, a gyors hallásfeldolgozási képesség, a fonológiai tudatosság és a betűzés kapcsán.

A ritmika és a diszlexia további összefüggéseit vizsgálva Tiernay és Kraus (2013) kimutatták, hogy a tapsolás általi metrumreprodukcióban nyújtott teljesítmény párhuzamba állítható az olvasási teljesítménnyel, a figyelemmel, a hallásfeldolgozással, és a végrehajtó funkciókkal. A felállított gondolatmenet azonban egy gyenge pontot rejt magában, méghozzá magának a tapsolásnak a mechanizmusát. Ez a mozgás ugyanis számos terület szinkronizált és zökkenőmentes müködése által képes csak a pontos metrum visszaadására, mint például a nagymozgások finomításának képessége, a lateralitás problémamentessége, a figyelmi kontroll, a megfelelő tér-orientációs és hallásfeldolgozási képességek. A vizsgálat során az olvasási nehézséggel küzdők nagyon változatos metrumtapsolási teljesítményének háttértényezőire a folyamat összetettsége révén így nem derült fény, viszont az korrelációt mutatott az időkorlát nélküli álszó- és szóolvasással, és az időkorlátos álszóolvasással is.

A Flaugnacco és mtsai (2014) által végzett kutatás a metrikai képességeket több aspektusból vizsgálva, a tapsolás mechanizmusát ceruzával való kopogásra váltva már szorosabb összefüggést mutatott a fonológiai tudatosság és a metrikai képességek között, melyeket a ritmusreprodukció dimenziójában is alátámasztottak. Más vizsgálatok kiemelik az olvasás és a feldolgozási idő közötti összefüggést is (Goswami és mtsai, 2002; Thomson és Goswami, 2008). Egy, a ritmikai fejlesztést jobban előtérbe helyező hangszeres oktatás e kutatási eredmények függvényében megfelelő eszköz lehet az olvasási zavar, nehézség prevenciós és intervenciós eljárásaként.

\section{Összegzés}

Számos korábbi kutatás bizonyította a zenetanulásnak a személyiség fejlődésére és a tanulmányi teljesítményre gyakorolt pozitív transzferhatását. $E$ vizsgálatokból építkezve elindult a zenei fejlesztés szerepének feltárása a tanulási zavar kezelésében. A leginkább kutatott olvasási zavar kapcsán lezajlott vizsgálatok a zene és a nyelv feldolgozása közti párhuzamokra építenek (Bernstein, 1979; Cason és mtsai, 2015; Giacobbe, 1972; Weiss és mtsai, 2015; Zatorre és Baum, 2012), kihasználva a zenetanulásban rejlő komplex fejlesztési lehetőségeket. Az olvasási zavar prevenciója és kezelése a különböző szenzitív időszakok mentén, a szenzomotórium rendszerére építve már óvodás kortól ajánlatott (Gyarmathy, 2015), ahol a zenei fejlesztés megkezdése nagyon hatékony a gyermekek fejlődésének elősegítésében (Janurik és Józsa, 2012). A későbbiekben a hangszeres tanulás optimális továbblépési lehetőségként szolgál a még 
eredményesebb fejlesztés érdekében. Az elsődlegesen népzenei alapokon nyugvó zeneoktatásunk ehhez megfelelő táptalajt biztosít, hiszen szorosan kötődik anyanyelvünkhöz, mind a zene, mind a beszélt nyelv viszonylatában. A már ismertetett kutatási eredmények függvényében azonban elmondható, hogy az olvasási teljesítmény javulásában szerepet játszó tényezők fejlődésének érdekében a hangmagasság-észlelés és kiemelten a ritmikai készségek fejlesztésére érdemes nagyobb hangsúlyt fektetni. Ezen készségeknek ugyanis fontos szerepük van: a beszéd dekódolása során a hangsúlyozás és az érzelmi állapotok felismerését segítik, a beszédfeldolgozás kapcsán pedig a fonológiai tudatosság javulását, és a hangzók gyorsabb időbeli feldolgozását teszik lehetővé. A fejlesztéshez hangszertanulást társítva a vizuális, auditív, szenzoriális és motoros készségek, képességek intenzívebben fejlődnek, és ezek összehangolása által az agyféltekék közötti összeköttetés is megerősíthető. A diszlexia megelőzése, kezelése így alapvetően nem a gyermekek számára nehézséget jelentő problémák direkt, sokszor csalódottságot eredményező fejlesztőóráit jelenti, hanem a zenélés új világának megismerése által, közvetetten, rengeteg pozitív élménnyel és a siker lehetőségével segíti őket a jobb olvasási és tanulási teljesítmény elérésében.

\section{Felhasznált irodalom}

American Psychiatric Association (2013): Diagnostic and Statistical Manual of Mental Disorders, Fifth Edition. American Psychiatric Association, Arlington, VA.

Anvari, S. H., Trainor, L. J., Woodside, J., és Levy, B. A. (2002): Relations among musical skills, phonological processing, and early reading ability in preschool children. Journal of Experimental Child Psychology, 83. 2. sz. ,111-130.

Barkóczi llona és Pléh Csaba (1978): Kodály zenei nevelési módszerének pszichológiai hatásvizsgálata. Kodály Zoltán Zenepedagógiai Intézet, Kecskemét.

Bernstein, L. (1979): A megválaszolatlan kérdés. Zenemükiadó, Budapest.

Besson, M., Chobert, J. és Marie, C. (2011): Transfer of training between music and speech: common processing, attention, and memory. Frontiers in Psychology, 2., 1-12.

Bishop-Liebler, P., Welch, G., Huss, M., Thomson, J. M. és Goswami, U. (2014): Auditory Temporal Processing Skills in Musicians with Dyslexia. Dyslexia, 20. 3. sz., 261-280.

Cason, N., Astésano, C. és Schön, D. (2015): Bridging music and speech rhythm: Rhythmic priming and audio-motor training affect speech perception. Acta Psychologica, 155., 43-50.

Chobert, J., François, C., Velay, J-L. és Besson, M. (2014): Twelve Months of Active Musical Training in 8- to 10-Year-Old Children Enhances the Preattentive Processing of Syllabic Duration and Voice Onset Time. Cerebral Cortex, 24. 4. sz., 956-967.

Csépe Valéria (2006): Az olvasó agy. Akadémiai Kiadó, Budapest.

Dékány Judit és Mohai Katalin (2012): Egyéb pszichés fejlődési zavarral küzdő gyermekek, tanulók komplex vizsgálatának diagnosztikus protokollja - Specifikus tanulási zavarok (írott nyelvhasználat zavarai, diszkalkulia). In: Torda Ágnes (szerk.): Diagnosztikai kézikönyv. Educatio Társadalmi Szolgáltató Nonprofit Kft, Budapest, 1-88.

Erős Istvánné (1993): Zenei alapképesség. Akadémiai Kiadó, Budapest.

Flaugnacco, E., Lopez, L., Terribili, Ch., Zoia, S., Buda, S., Tilli, S., Monasta, L., Montico, M., Sila, A., Ronfani, L. és Schön, D. (2014): Rhythm perception and production predict reading abilities in developmental dyslexia. Frontiers in Human Neuroscience, 8. 1-32.

Foran, L. M. (2009): Listening to Music: Helping Children Regulate Their Emotions and Improve Learning in the Classroom. Educational Horizons, 88. 1. sz., 51-58.

Francois, C., Chobert, J., Besson, M. és Schön, D. (2012): Music Training for the Development of Speech Segmentation. Cerebral Cortex, 23. 9. sz., 2038-2043.

Gaiser, E., Sandmann, P., Jancke, L. és Meyer, M. (2010): Refinement of metre perception training increases hierarchical metreprocessing. European Journal of Neuroscience, 32. 11. sz., 1979-1985. 
Gaser, Ch. és Schlaug, G. (2003): Brain Structures Differ between Musicians and Non-Musicians. The Journal of Neuroscience, 23. 27. sz., 9240-9245.

Gazzaniga, M. S. (2008): Arts and Cognition: Findings Show Strong Links. In: 2008 Progress Report on Brain Research, Dana Press, New York.

Giacobbe, G. A. (1972): Rhythm Builds Order in Brain-Damaged Children. Music Educators Journal, 58. 8. sz., 40-43.

Gombás Judit és Stachó László (2006): Matematikai és zenei képességek vizsgálata 10-14 éves gyerekeknél In: Majoros Pál (szerk.): BGF Tudományos Évkönyv 2006: Stratégiák 2007 és 2013 között. Konferencia helye, ideje: Budapest, Magyarország, 2006.11.092006.11.10. Budapest: Budapesti Gazdasági Főiskola, 404-416.

Gordon, R. L., Magne, C. L. és Large, E. W. (2011): EEG correlates of song prosody: a new look at the relationship between linguistic and musical rhythm. Frontiers in Psychology, 2. 352.

Goswami, U., Thomson, J., Richardson, U., Stainthorp, R., Hughes, D., Rosen, S. és Scott, S. K. (2002): Amplitude Envelope Onsets and Developmental Dyslexia: A New Hypothesis. Proceedings of the National Academy of Sciences of the United States of America, 99. 16. sz., 10911-10916.

Gyarmathy Éva (2007): Diszlexia. A specifikus tanítási zavar. Lélekben Otthon Kiadó, Budapest.

Gyarmathy Éva (2013): Diszlexia a digitális korszakban. Múszaki Kiadó, Budapest.

Gyarmarhy Éva (2015): Tehetségvizsgálatok, Kognitív Profil teszt, Érdeklődés Térképe - fejlesztő pedagógusoknak. Előadás. ELTE PPK Kazinczy u. 23-27. 2015.11.28. 09.00 - 17.00

Huss, M., Verney, J.P., Fosker, T., Mead, N. és Goswami, U. (2011): Music, rhythm, rise time perception and developmental dyslexia: Perception of musical meter predicts reading and phonology. Cortex, 47. 6. sz., 674-689.

Ibbotson, N. R. és Morton, J. (1981): Rhythm and dominance. Cognition, 9. 2. sz., 125-138.

Janurik Márta (2008): A zenei képességek szerepe az olvasás elsajátításában. Magyar Pedagógia, 108. 4. sz., 289-317.

Janurik Márta és Józsa Krisztián (2012): Findings of a three months long music training programme. Hungarian Educational Research Journal, 2. 4. sz., 2-14.

Janurik Márta és Józsa Krisztián (2013): A zenei képességek fejlődése 4 és 8 éves kor között. Magyar Pedagógia, 113. 2. sz., 75-99.

Janurik Márta és Józsa Krisztián (2016a): A zenei képességek összefüggése a DIFER készségekkel óvodáskorban. Neveléstudomány: Oktatás - Kutatás - Innováció, 4. 1. sz. 49-69.

Janurik Márta és Józsa Krisztián (2016b): Enyhén értelmi fogyatékos gyermekek zenei képességének fejlettsége. Magyar Pedagógia, 106. 1. sz., 25-50.

Janurik Márta és Józsa Krisztián (2016c): Zene és tanulás. Tanító, 54. 1. sz., 21-24.

Józsa Krisztián és Steklács János (2009): Az olvasástanítás kutatásának aktuális kérdései. Magyar Pedagógia, 109. 4. sz.,365-397.

Józsa Krisztián és Morgan, George A. (2014): Developmental changes in cognitive persistence and academic achievement between grade 4 and grade 8 . European Journal of Psychology of Education, 29. 3. sz., 521-535.

Józsa Krisztián, Wang Jun, Barrett Karen és Morgan George (2014): Age and cultural differences in self-perceptions of mastery motivation and competence in American, Chinese, and Hungarian school age children. Child Development Research, 1-16.

Józsa Krisztián (2016): Kihívások és lehetőségek az óvodai fejlesztésben. Iskolakultúra, 26. 4. sz., 59-74.

Kokas Klára (1972): Képességfejlesztés zenei neveléssel. Zenemükiadó Vállalat, Budapest.

Kraus, N. és Chandrasekaran, B. (2010): Music training for the development of auditory skills. Nature Reviews Neuroscience, 11. 8. sz., 599-605.

Kraus, N., Slater, J., Thompson, E.C., Hornickel, J., Strait, D.L., Nicol, T. és White-Schwoch, T. (2014): Music Enrichment Programs Improve the Neural Encoding of Speech in At-Risk Children. The Journal of Neuroscience, 34. 36. sz., 11913-11918. 
Krings, T., Töpper, R. F., Foltys, H., Sparing, R., Erberich, S. G., Willmes, K. és Thron, A. K. (2000): Cortical activation patterns during complex motor tasks in piano players and control subjects. A functional magnetic resonance imaging study. Neuroscience letters, 278. 3. sz., 189-193.

Levitin, D. J. (2006): This is your brain on music: the science of a human obsession. Dutton, Bibliotheksverbund Bayern.

Lohmann, B. (2000): Diszlexiások az iskolában. Akkord Kiadó, Budapest.

Marton-Dévényi Éva (2001): Anyanyelvi-zenei helyesírás fejlesztés - diszgráfiakezelés. Fejlesztő Pedagógia, 21. 1. sz., 33-37.

Michel, P. (1964): Zenei képesség - zenei készség. Zenemükiadó Vállalat, Budapest.

Moreno, S., Marques, C., Santos, A., Santos, M., Castro, S.L: és Besson, M. (2009): Musical Training Influences Linguistic Abilities in 8-Year-Old Children: More Evidence for Brain Plasticity. Cerebral Cortex, 19. 3. sz., 712-723.

Murphy-Ruiz, P., Penaloza-Lopez, Y., Garcia-Pedroza, F., és Poblano, A. (2013): Right cerebral hemisphere and central auditory processing in children with developmental dyslexia. Arquivos De Neuro-Psiquiatria, 71. 11. sz., 883-889.

Musacchia, G., Strait, D. és Kraus, N. (2008): Relationships between behavior, brainstem and cortical encoding of seen and heard speech in musicians and non-musicians. Hear Res. 241. 1-2. sz., 34-42.

OECD-tanulmány (2009): Az agy müködése. forrás: http://www.ofi.hu/tudastar/oecdtanulmanyok/agy-mukodese, utolsó megtekintés: 2015.04.13.

Overy, K. (2003): Dyslexia and music - From timing deficits to musical intervention. The neurosciences and music, Annals of the New York Academy of Sciences. 999. 1. sz., 497-505.

Patel, A. D. és Iversen, J. R. (2007): The linguistic benefits of musical abilities. Trends in Cognitive Sciences, 11. 9. sz., 369-373.

Peretz, I. és Zatorre, R. J. (2005): Brain organization for music processing. Annual Review of Psychology, 56., 89-115.

Peterson, C. W. és Madsen, C. K. (2010): Encouraging Cognitive Connections and Creativity in the Music Classroom. Music Educators Journal, 97. 2. sz., 25-29.

Phillips-Silver, J. és Trainor, L, J. (2005): Feeling the Beat: Movement Influences Infant Rhythm Perception. Science, 308. 1430.

Port, R. F. (2003): Meter and Speech. Journal of Phonetics, 31. 3-4. sz., 599-611.

Schellenberg, E. G. (2004): Music lessons enhance IQ. Psychological Science, 15. 8. sz., 511-514.

Su, Yi-Huang és Pöppel, E. (2012): Body movement inhances the extraction of temporal structures in audirory sequences. Psychological Research, 76. 3. sz., 373-382.

Tallal, P. és Gaab, N. (2006): Dynamic auditory processing, musical experience and language development. Trends in Neurosciences, 29. 7. sz., 382-390.

Thomson, J. M., és Goswami, U. (2008): Rhythmic processing in children with developmental dyslexia: auditory and motor rhythms link to reading and spelling. Journal of PhysiologyParis, 102. 1-3. sz., 120-129.

Tierney, A. T. és Kraus, N. (2013): The ability to tap to a beat relates to cognitive, linguistic, and perceptual skills. Brain and Language, 124. 225-231.

Tillmann, B. (2012): Music and Language Perception: Expectations, Structural Integration, and Cognitive Sequencing. Topics In Cognitive Science, 4. 4. sz., 568-584.

Turmezeyné Heller Erika, Máth János és Balogh László (2005): Zenei képességek és iskolai fejlesztés. Magyar Pedagógia, 105. 2. sz., 207-236.

Tyeplov, B. M. (1960): A zenei képességek pszichológiája. Tankönyvkiadó, Budapest.

Vuust, P., Pallesen, K. J., Bailey, Ch., van Zuijen, T. L., Gjedde, A., Roepstroff, A. és Östergaard, L. (2005): To musicians, the message is in the meter: Pre-attentive neuronal responses to incongruent rhythm are left-lateralized in musicians. Neurolmage, 24. 2. sz., 560-564.

Weiss, M. W., Gavin, X. és Bidelman, M. (2015): Listening to the Brainstem: Musicianship Enhances Intelligibility of Subcortical Representations for Speech. The Journal of Neuroscience, 35. 4. sz., 1687-1691. 
Wong, P. C. M., Skoe, E., Russo, N. M., Dees, T. és Kraus, N. (2007): Musical experience shapes human brainstem encoding of linguistic pitch patterns. Nature Neuroscience, 10. 4. sz., 420-422.

World Federation of Neurology (1968): Report of research group on developmental dyslexia and world illiteracy. Bulletin of the Orton Society, 18. 21-22.

Zatorre, R. J., Belin, P. és Penhune, V. B. (2002): Structure and function of auditory cortex: music and speech. Trends in Cognitive Sciences, 6. 1. sz., 37-46.

Zatorre, R. és Baum, S. (2012): Musical melody and speech intonation: singing a different tune. Plos Biology, 10. 7. sz., 1-6.

Zatorre, R. J. (2013): Predispositions and plasticity in music and speech learning: neural correlates and implications. Science, 342. 6158. sz., 585-589.

Zsolnai Anikó és Józsa Krisztián (2002): A szociális készségek kritériumorientált fejlesztésének lehetőségei. Iskolakultúra, 12. 4. sz., 12-22.

Zsolnai Anikó és Józsa Krisztián (2003): Possibilities of criterion referenced social skill development. Journal of Early Childhood Research, 1. 2. sz., 181-196. 